NASA Technical Memorandum 106558

\title{
One-Step Synthesis of Dithiocarbamates from Metal Powders
}

\author{
Aloysius F. Hepp \\ Lewis Research Center \\ Cleveland, Ohio \\ David G. Hehemann \\ Kent State University \\ Kent, Ohio
}

Stan A. Duraj

Cleveland State University

Cleveland, Ohio

Eric B. Clark

Lewis Research Center

Cleveland, Ohio

William E. Eckles

Cleveland State University

Cleveland, Ohio

Phillip E. Fanwick

Purdue University

West Lafayette, Indiana

Prepared for the

\section{Fall Meeting}

sponsored by the Materials Research Society

Boston, Massachusetts, November 29-December 3, 1993

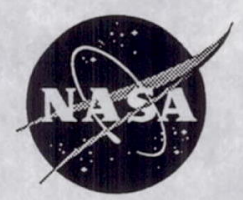

National Aeronautics and

Space Administration 


\section{ONE-STEP SYNTHESIS OF DITHIOCARBAMATES FROM METAL POWDERS}

ALOYSIUS F. HEPP, ${ }^{*}$ DAVID G. HEHEMANN, ${ }^{* *}, \ddagger$ STAN A. DURAJ, ${ }^{\circ}$ ERIC B. CLARK, WILLIAM E. ECKLES, $\dagger^{\dagger}$ AND PHILLIP E. FANWICK ${ }^{\dagger \dagger}$

*NASA Lewis Research Center, M.S. 302-1, Cleveland, OH 44135

** School of Technology, Kent State University, Kent, OH 44242

tDepartment of Chemistry, Cleveland State University, Cleveland, OH 44115

ttDepartment of Chemistry, Purdue University, West Lafayette, IN 47907

\section{ABSTRACT}

Neutral metal dithiocarbamate complexes $\left(\mathrm{M}\left(\mathrm{NR}_{2} \mathrm{CS}_{2}\right)_{x}\right)$ are well-known precursors to metal sulfides, a class of materials with numerous technological applications. We are involved in a research effort to prepare new precursors to metal sulfides using simple, reproducible synthetic procedures. We describe the results of our synthetic and characterization studies for $\mathrm{M}=\mathrm{Fe}, \mathrm{Co}$, $\mathrm{Ni}, \mathrm{Cu}$, and In. For example, treatment of metallic indium with tetramethylthiuramdisulfide (tmtd) in 4-methylpyridine (4-Mepy) at $25^{\circ} \mathrm{C}$ produces a new homoleptic indium (III) dithiocarbamate, In $\left(\mathrm{N}\left(\mathrm{CH}_{3}\right)_{2} \mathrm{CS}_{2}\right)_{3}(\mathrm{I})$, in yields of over $60 \%$. The indium (III) dithiocarbamate was characterized by X-ray crystallography; (I) exists in the solid state as discrete distorted-octahedral molecules. Compound (I) crystallizes in the P1bar (No. 2) space group with lattice parameters: $a=9.282(1)$ $\AA, b=10.081(1) \AA, c=12.502 \AA, \alpha=73.91(1)^{\circ}, \beta=70.21(1)^{\circ}, \gamma=85.84(1)^{\circ}$, and $Z=2 . X-$ ray diffraction and mass spectral data were used to characterize the products of the analogous reactions with $\mathrm{Fe}, \mathrm{Co}, \mathrm{Ni}$, and $\mathrm{Cu}$. We discuss both use of dithiocarbamates as precursors and our approach to their preparation.

\section{INTRODUCTION}

Technological applications for metal sulfides are numerous. Many applications take advantage of the photoelectrical or electrical properties of these materials in electronic applications such as solar cells, infrared detectors, light-emmiting diodes, and transistors (e.g. CdS, GaS, and $\mathrm{CuInS}_{2}$ ) $[1,2]$. Chevrel phases are superconducting, for example $\mathrm{PbMo}_{6} \mathrm{~S}_{8}$ has a $\mathrm{T}_{c}$ of $21 \mathrm{~K}$ [3]. An example of a chemical application is the use of heterogeneous systems such as Co-promoted molybdenum sulfide ( $\mathrm{Ni}$ or $\mathrm{W}$ are sometimes substituted for $\mathrm{Co}$ and $\mathrm{Mo}$ ) on $\gamma$-alumina catalysts for metal and sulfur removal under $\mathrm{H}_{2}$ from crude oil, this allows efficient or environmentally sound use of "dirtier" feedstocks [4]. Chemical sensitization to form $\operatorname{AgAu}_{x} S_{y}$ clusters on silver halide grains is an integral step in producing photographic film [5]. It is also interesting to note that many enzymes and electron transfer proteins have metal-sulfide cluster active sites [6].

As part of an in-house and external effort to synthesize and use metal sulfides and selenides as precursors for photovoltaic and related optoelectronic applications [2,7-9], we are exploring synthetic aspects of metal calcogenide chemistry. One very well-studied class of compounds is neutral, homoleptic metal dithiocarbamates of the formula $\mathrm{M}\left(\mathrm{NR}_{2} \mathrm{CS}_{2}\right)_{\mathrm{x}}$ [10]. There are several typical synthetic routes to these compounds including reaction of $\mathrm{CS}_{2}$ with metal amide complexes $\left(\mathrm{M}\left(\mathrm{NR}_{2}\right)_{\mathrm{x}}\right)$, reaction of metal chlorides with $\mathrm{CS}_{2}$ in the presence of amines, and direct reaction of metal halides with the sodium dithiocarbamate salt [6]. Less typically discussed are reactions involving metal powders $[11,12]$. We have determined that a wide range of metals will react directly with tetraalkylthiuram disulfides to form homoleptic dithiocarbamates including $\mathrm{Fe}, \mathrm{Co}$, $\mathrm{Ni}, \mathrm{Cu}$, and $\mathrm{In}$, in the case of indium producing a new dithiocarbamate $\left(\mathrm{N}\left(\mathrm{CH}_{3}\right)_{2} \mathrm{CS}_{2}\right)_{3}(\mathrm{I})$. We also discuss mass spectral data on several transition metal complexes and relate it to their potential uses as precursors in chemical vapor deposition (CVD) and other deposition technologies.

\#- Senior Research Fellow/NASA Lewis Research Center Resident Research Associate. 


\section{EXPERIMENTAL}

All manipulations of moisture and air-sensitive materials were done under an inert atmosphere by standard Schlenk techniques on a double-manifold vacuum line or in a Vacuum Atmospheres Co. glovebox equipped with a HE-493 dri-train. Solvents were freshly distilled from benzophenone ketyl prior to use. Metal powders were obtained from Strem Chemicals, Newburyport, MA. Sulfur compounds were obtained from Aldrich Chemical Co., Milwaukee, WI. Infrared spectra were recorded on a Perkin-Elmer 599B spectrophotometer. Electron impact mass spectra $\left(25\right.$ and $70 \mathrm{eV}, 150^{\circ} \mathrm{C}$ ) were recorded on a Finnigan TSQ-45 mass spectrometer. Single crystal X-ray analyses were done on an Enraf-Nonius CAD-4 diffractometer.

\section{RESULTS AND DISCUSSION}

Metal dithiocarbamates were typically prepared by reaction of metal powder $(\mathrm{M}=\mathrm{Fe}, \mathrm{Co}, \mathrm{Ni}$, $\mathrm{Cu}$, and $\mathrm{In})(0.50 \mathrm{~g})$ and stoichiometric amounts of tetraalkylthiuramdisulfides (for $\mathrm{R}=\mathrm{Me}$, tmtd; $\mathrm{R}=\mathrm{Et}$, tetd) in $35 \mathrm{~mL}$ of 4-methylpyridine at ambient temperature for several days, equation 1. The reaction was filtered, and the resulting solution was layered with hexanes. Hexanes, $150 \mathrm{~mL}$, was added to the resulting dark brown or black material to further precipitate solid.

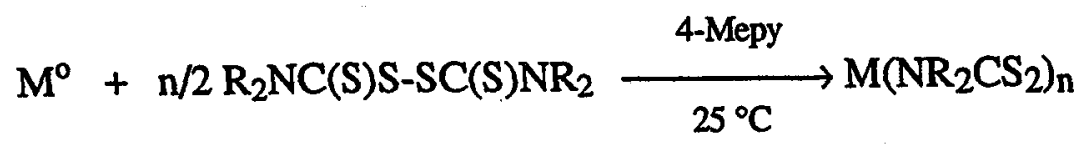

For example, treatment of metallic indium with tmtd in 4-Mepy at $25^{\circ} \mathrm{C}$ produces In $\left(\mathrm{N}\left(\mathrm{CH}_{3}\right)_{2} \mathrm{CS}_{2}\right)_{3}(\mathrm{I})$, in yields of over $60 \%$. The indium (III) dithiocarbamate was characterized by X-ray crystallography; (I) exists in the solid state as discrete distorted-octahedral molecules, figure 1. Compound (I) is only the second indium dithiocarbamate to be structurally characterized [13]. Compound (I) crystallizes in space group P1bar $($ No. 2), lattice parameters: $a=9.282(1) \AA$, $\mathrm{b}=10.081(1) \AA, c=12.502 \AA, \alpha=73.91(1)^{\circ}, \beta=70.21(1)^{\circ}, \gamma=85.84(1)^{\circ}$, and $Z=2$. Single crystal X-ray diffraction data were collected as well for $\mathrm{Cu}\left(\mathrm{N}\left(\mathrm{C}_{2} \mathrm{H}_{5}\right)_{2} \mathrm{CS}_{2}\right)_{2}$, which has been previously structurally characterized [14]. The complexes that were isolated were both divalent (M $=\mathrm{Ni}$ and $\mathrm{Cu})$ and trivalent $(\mathrm{M}=\mathrm{Fe}, \mathrm{Co}$, and $\mathrm{In})$ for $\mathrm{R}=\mathrm{Me}$ and Et with structures analogous to the $\mathrm{Cu}$ and the In, respectively.
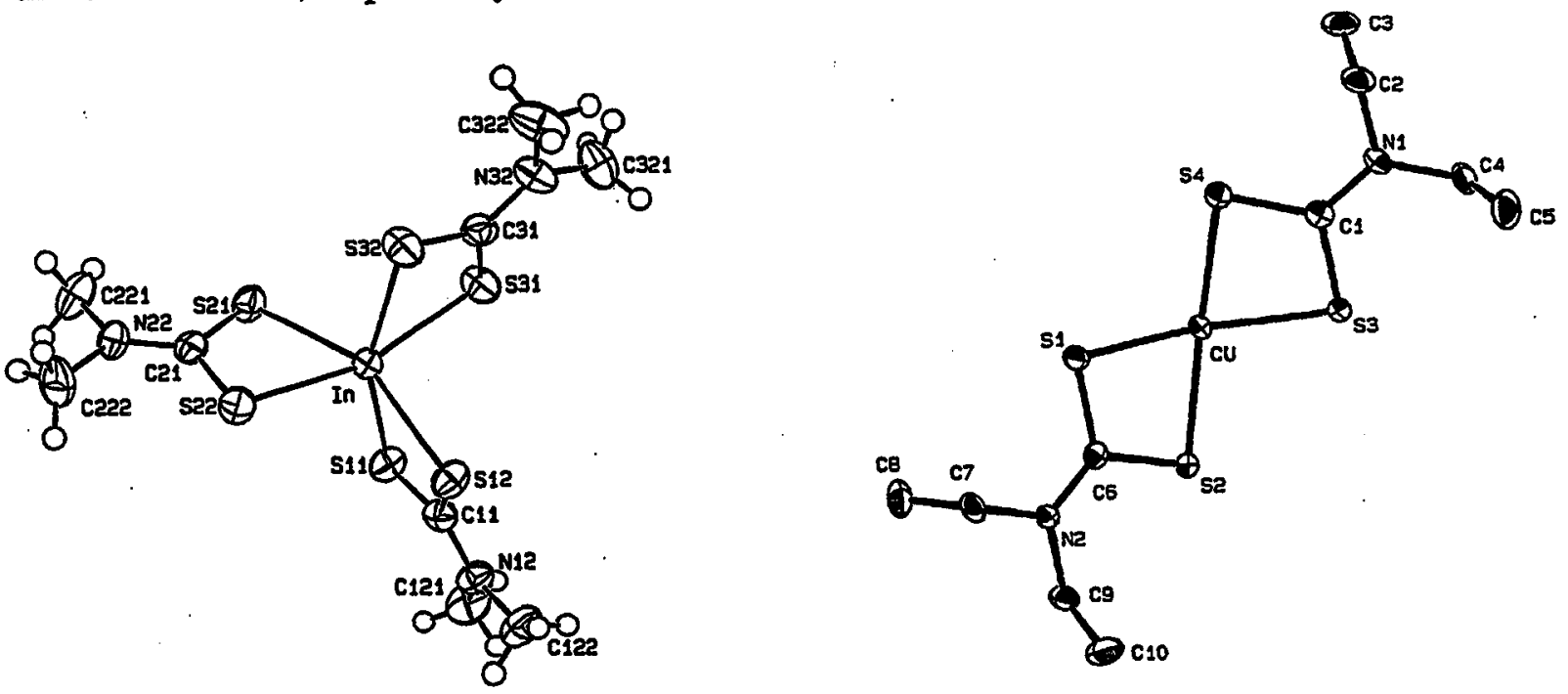

Figure 1. - ORTEP drawings of $\mathrm{In}\left(\mathrm{N}\left(\mathrm{CH}_{3}\right)_{2} \mathrm{CS}_{2}\right)_{3}$ and $\mathrm{Cu}\left(\mathrm{N}\left(\mathrm{C}_{2} \mathrm{H}_{5}\right)_{2} \mathrm{CS}_{2}\right)_{2}$ with key atoms labelled. The thermal ellipsoids enclose $50 \%$ of electron density. 
Table 1.

MASS SPECTRA OF METAL DIMETHYLDITHIOCARBAMATES

First numbers are $m / z$ values. Numbers in brackets are relative intensities.

\begin{tabular}{||c|c|c|c|c||}
\hline \multirow{2}{*}{ ION } & \multicolumn{5}{|c|}{ METALS M } \\
\cline { 2 - 5 } & $\mathrm{Cu}$ & $\mathrm{Co}$ & $\mathrm{Fe}$ & $\mathrm{Ni}$ \\
\hline $\mathrm{M}^{+}$ & $63,65(11.9,5.2)$ & $59(2.4)$ & $56(10.3)$ & $58,60(5.6,1.8)$ \\
\hline$\left[\mathrm{CH}_{3} \mathrm{NCS}^{+}\right.$ & $73(15.8)$ & $73(14.0)$ & $73(12.1)$ & $73(14.7)$ \\
\hline$\left[\left(\mathrm{CH}_{3}\right)_{2} \mathrm{NCS}^{+}\right.$ & $88(100)$ & $88(100)$ & $88(100)$ & $88(100)$ \\
\hline$\left[\left(\mathrm{CH}_{3}\right)_{2} \mathrm{NCS}_{2}\right]^{+}$ & $120(10.2)$ & $120(9.3)$ & $120(10.1)$ & $120(9.4)$ \\
\hline $\mathrm{MS}_{2}^{+}$ & $127,129(2.9,1.5)$ & $123(.7)$ & $120(-)$ & $122,124(2.9,0.8)$ \\
\hline$\left[\mathrm{MSCNCH}_{3}\right]^{+}$ & $136,138(14.3,7.1)$ & $132(2.0)$ & $129(3.0)$ & $131,133(4.7,2.1)$ \\
\hline$\left[\mathrm{MS}_{2} \mathrm{CN}\left(\mathrm{CH}_{3}\right)_{2}\right]^{+}$ & $183,185(28.8,15.9)$ & $179(6.2)$ & $176(15.2)$ & $178,180(11.3,7.0)$ \\
\hline$\left[\mathrm{M}\left(\mathrm{S}_{2} \mathrm{CN}\left(\mathrm{CH}_{3}\right)_{2}\right)_{2}\right]^{+}$ & $303,305(74.0,56.8)$ & $299(49.7)$ & $296(84.7)$ & $298,300(37.5,20.7)$ \\
\hline$\left[\mathrm{M}\left(\mathrm{S}_{2} \mathrm{CN}\left(\mathrm{CH}_{3}\right)_{2}\right)_{3}\right]^{+}$ & $423,425(-,-)$ & $419(13.9)$ & $416(8.3)$ & $418,420(-,-)$ \\
\hline \hline
\end{tabular}


It was previously reported that room-temperature reaction of copper and nickel powders with sodium dithiocarbamates and photochemical reaction of copper powder with tetraalkylthiuramdisulfides (tatd) in $\mathrm{CHCl}_{3}$ produce metal dithiocarbamates [11,12]. We and others have discovered that in strong basic, coordinating solvents such as 4-MePy, species such as $\mathrm{S}_{8}, \mathrm{REER}(\mathrm{R}=$ alkyl or aryl, $\mathrm{E}=\mathrm{S}$ or $\mathrm{Se})$ and $\left(\mathrm{C}_{6} \mathrm{H}_{5} \mathrm{CO}\right)_{2} \mathrm{O}_{2}$ will oxidize metal powders [15-19]. The advantage of reaction (1) is the lack of by-products. Production of dithiocarbamates via oxidation of metal powders results in a much greater control of impurities, first by the use of metal powders as a starting material and second by simplicity in the chemistry that resultis in only one product.

The dithiocarbamates prepared for $\mathrm{M}=\mathrm{Fe}, \mathrm{Co}, \mathrm{Ni}$, and $\mathrm{Cu}$ were examined by mass spectrometry. A diagram of the instrument used in these studies is shown in figure 2. A summary of relevant mass spectral data is given in table 1. All of the metal complexes show characteristic peaks corresponding to breakdown of the dimethyldithiocarbamate residues. Each compound gives an ion at $\mathrm{m} / \mathrm{z} 120$ corresponding to the dimethyldithiocarbamate residue itself. Each spectrum has as its base peak, $\mathrm{m} / \mathrm{z} 88$ with $100 \%$, consistent with loss of a sulfur atom, $\left(\mathrm{CH}_{3}\right)_{2} \mathrm{NCS}^{+}$. Finally, each compound has apeak at $\mathrm{m} / \mathrm{z}$ corresponding to the methyl isocyanate ion produced by the loss of a methyl and sulfide ion. The organic fragments for all metal complexes were of approximately the same intensity.

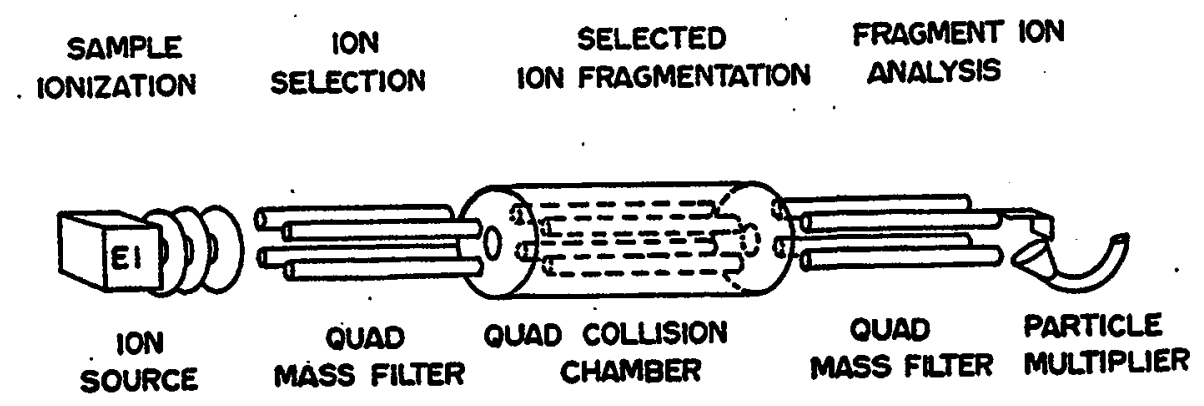

Figure 2. - Schematic diagram of Finnigan TSQ-45 mass spectrometer used in this study.

The divalent copper and nickel complex spectra contain a highest mass peak at $\mathrm{m} / \mathrm{z} 303$ for the ${ }^{63} \mathrm{Cu}$ isotope and a m/z 298 peak for the ${ }^{58} \mathrm{Ni}$ isotope. This peak indicates that the $\mathrm{Cu}$ or $\mathrm{Ni}$ atom is bound to two dimethyldithiocarbamate residues in the complex, the parent ion. This indicates that the complexes are fairly volatile and stable in the gas phase, an important attribute for a material precursor. In addition to this peak, these compounds display peaks corresponding to loss of one of the dimethyldithiocarbamate groups ( $\mathrm{Cu}: 183$; $\mathrm{Ni}$ : 178) and a lower intensity peak resulting from further loss of $\mathrm{a} \mathrm{CH}_{3} \mathrm{~S}$ fragment to result in a metal methyl isocyanide fragment (Cu: 136; $\mathrm{Ni}$ : 131). Finally, both $\mathrm{Cu}$ and $\mathrm{Ni}$ have less intense peaks that correspond to $\mathrm{M}^{+}$and weak $\mathrm{MS}_{2}{ }^{+}$peaks.

The parent ions of the trivalent $F e$ and $C o$ occur at $\mathrm{m} / \mathrm{z} 416$ and 419 , respectively. The parent ions of both trivalent complexes are less intense than for $\mathrm{Cu}$ and $\mathrm{Ni}$, expected due to the highest molecular weights; a crude ordering of volatilities from this data is $\mathrm{Cu} \gg \mathrm{Ni}>\mathrm{Co}-\mathrm{Fe}$. The dithiocarbamate-loss fragment $\mathrm{ML}_{2}{ }^{+}$(Co: 299, Fe: 296) of both $\mathrm{Fe}$ and $\mathrm{Co}$ are much more intense than the corresponding parent ions and the analagous $\mathrm{Ni}$ and $\mathrm{Cu}$ species $\mathrm{ML}+$. The rationale for the intensity of these ions is two-fold: the stability of $\mathrm{Fe}^{2+}$ and $\mathrm{Co}^{2+}$ relative to monovalent $\mathrm{Ni}$ and $\mathrm{Cu}$ and the greater volatility of a lower-mass fragement. The stability argument is born out by the relative wekness of the $\mathrm{FeL}^{+}$and $\mathrm{CoL}^{+}$peaks. Finally, the $\mathrm{M}^{+}$peaks of $\mathrm{Co}$ and $\mathrm{Fe}$ are weak, $\mathrm{Fe}$ approximating $\mathrm{Ni}$ while $\mathrm{Co}$ is weakest, approximately following trends in the metals' boiling points [20]. The $\mathrm{MS}_{2}{ }^{+}$ions for $\mathrm{Fe}$ and $\mathrm{Co}$ are essentially non-existent. 
Metal dithiocarbamates have been shown to cleanly produce metal sulfides, both as bulk [21] and thin-film material $[22,23]$. Work by others is focused on producing dithiocarbamates with substituted or additional ligands to enhance volatility [24-26] and/or minimize dimerization that occurs with $\mathrm{Zn}$ diethyldithiocarbamate, for example $[27,28]$. For these complexes, the chemistry that we describe would be useful as a method to prepare a variety of dithiocarbamates for further reaction to the sulfide precursors. Another example of use of dithiocarbamates is the use of copper di-n-butyldithiocarbamate to prepare a single-molecule precursor to $\mathrm{CuInS}_{2}$ [29]. Work is currently underway in our labs to exploit this chemistry to prepare precursors for binary and ternary sulfides.

\section{CONCLUSIONS}

We have described a simple one-step synthesis to metal dithiocarbamtes by oxidation of metal powders with dialkylthiuram dilsulfides in a basic coordinating solvent. Dithiocarbamates are excellent precursors to metal sulfides, an important class of materials for a number of applications. The structure of $\operatorname{In}\left(\mathrm{N}\left(\mathrm{CH}_{3}\right)_{2} \mathrm{CS}_{2}\right)_{3}$, a distorted octahedron and only the second structurallycharacterized indium dithiocarbamate, was briefly described. Mass spectral data on $\mathrm{Fe}, \mathrm{Co}, \mathrm{Ni}$, and $\mathrm{Cu}$ dimethyldithiocarbamate indicate that all four are reasonably volatile. Both the divalent and trivalent compounds had fairly intense $\mathrm{ML}_{2}{ }^{+}$ion peaks, the $\mathrm{M}^{+}$and $\mathrm{MS}_{2}+$ (for $\mathrm{Cu}, \mathrm{Ni}$, and $\mathrm{Co}$ ) though weaker, were present. The mass spectral data demonstrates the key attributes of dithiocarbamates: volatility, relative stability in the gas phase, and ample decomposition pathways for clean production of metal sulfide.

\section{ACKNOWLEDGEMENTS}

A.F.H. (Director's Discretionary Fund), D.G.H (NASA Cooperative Agreement NCC3-318), S.A.D. (NASA Cooperative Agreement NCC3-162) and P.E.F. (NASA Cooperative Agreement NCC3-246) acknowledge support from NASA Lewis Research Center. We thank Profs. Andrew Barron of Harvard University, Mercouri Kanatzidis of Michigan State University, and Mark Hampden-Smith of the Univ. of New Mexico for pre-prints of their work.

\section{REFERENCES}

1. L.L. Kazmerski and S. Wagner, in Current Topics in Photovoltaics, edited by T. J. Coutts and J. D. Meakin (Academic Press, London, 1985) pp. 41-109.

2. A.N. MacInnes, M.B. Power, A.R. Barron, P.P. Jenkins, and A.F. Hepp, Appl. Phys. Lett. 62, 711 (1993).

3. R. Chevrel and M. Sargent, Topp. Curr. Phys. 32, 25 (1982).

4. O. Weisser and S. Landa, Sulfide Catalysts, Their Properties and Applications (Pergammon Press, New York, 1973).

5. D.A. Pitt, M.L. Rachu, and M.R.V. Sayhun, Photgr. Sci Eng. 25, 57 (1981).

6. F.A. Cotton and G. Wilkinson, Advanced Inorganic Chemistry, 5th ed. (John Wiley and Sons, New York, 1988).

7. W. Hirpo, S. Dhingra, A. Sutorik, and M.G. Kanatzidis, J. Am. Chem. Soc. 115, 1597 (1993). 
8. B.M. Basol, V.K. Kapur, A. Halani, and C. Leidholm, Solar Energy Materials and Solar Cells 29, 163 (1993).

9. M. Tabib-Azar, S. Kang, A.N. MacInnes, M.B. Power, A.R. Barron, P.P. Jenkins, and A.F. Hepp, Appl. Phys. Lett. 63, 625 (1993).

10. See the following extensive reviews: D. Coucouvanis, Prog. Inorg. Chem. 11, 233 (1970); D. Coucouvanis, Prog. Inorg. Chem. 26, 301 (1979).

11. T. Tetsumi, M. Sumi, M. Tanaka, and T. Shano, Polyhedron 4, 707 (1985).

12. T. Tetsumi, M. Sumi, M. Tanaka, and T. Shano, Polyhedron 5, 707 (1986).

13. K. Dymock, G.J. Palenik, J. Slezak, C.L. Raston, and A.H. White, J. Chem. Soc., Dalton Trans., 28 (1976).

14. B.H. O'Connor and E.N. Maslen, Acta. Cryst. 21, 828 (1966).

15. R. Kumar, H.E. Mabrouk, and D.G. Tuck, J. Chem. Soc., Dalton Trans., 1045 (1988).

16. G. Speier and V. Fulop, J. Chem. Soc., Dalton Trans., 2331 (1989).

17. E. Ramli, T.B. Rauchfuss, and C.L. Stern, J. Am. Chem. Soc. 112, 4043 (1990).

18. S. Dev, E. Ramli, T.B. Rauchfuss, and S.R. Wilson, Inorg. Chem. 30, 2514 (1991).

19. M.T. Andras, A.F. Hepp, S.A. Duraj, E.B. Clark, D.A. Scheiman, D.G. Hehemann, and P.E. Fanwick, Inorg. Chem. 32, 4150 (1993).

20. Handbook of Chemistry and Physics, edited by R.C. Weast, 55th ed. (Chemical Rubber Company Press, Cleveland, OHH, 1974).

21. I.R. Gelling, Rubber Chemistry and Technology 46, 524 (1973).

22. D.M. Frigo, O.F.Z. Khan, and P. O'Brien, J. Cryst. Growth 96, 989 (1989).

23. M.B. Hursthouse, M.A. Malik, M. Motevalli, and P. O'Brien, Polyhedron 11, 45 (1992).

24. M.B. Hursthouse, M.A. Malik, M. Motevalli, and P. O'Brien, Organometallics 10, 730 (1991).

25. M.A. Malik and P. O'Brien, Chem. Mater. 3, 999 (1991).

26. M.A. Malik, M. Motevalli, J.R. Walsh, and P. O'Brien, Organometallics 11, 3136 (1992).

27. Q. Powell, A. Gurav, T.T. Kodas, M.J. Hampden-Smith, D. Zeng, and M.L. Wang, submitted.

28. D. Zeng, M.J. Hampden-Smith, T.M. Alam, and A.L. Rheingold, submitted.

29. R. Nomura, S. Seki, and H. Matsuda, J. Mater. Chem. 2, 765 (1992). 
Public reporting burden for this collection of information is estimated to average 1 hour per response, including the time for reviewing instructions, searching existing data sources, gathering and maintaining the data needed, and completing and reviewing the collection of information. Send comments regarding this burden estimate or any other aspect of this collection of information including suggestions for reducing this burden, to Washington Headquarters Services, Directorate for Information Operations and Reports, 1215 Jefferson Davis Highway, Suite 1204, Arlington, VA 22202-4302, and to the Office of Management and Budget. Paperwork Reduction Project (0704-0188), Washington, DC 20503.

\begin{tabular}{|l|c|c|c|}
\hline 1. AGENCY USE ONLY (Leave blank) & $\begin{array}{c}\text { 2. REPOAT DATE } \\
\text { July } 1994\end{array}$ & $\begin{array}{r}\text { 3. AEPORT TYPE AND DATES COVERED } \\
\text { Technical Memorandum }\end{array}$ & $\begin{array}{r}\text { 5. FUNDING NUMBERS } \\
\hline \text { 4. TITLE AND SUBTITLE }\end{array}$
\end{tabular}

One-Step Synthesis of Dithiocarbamates from Metal Powders

6. AUTHOR(S)

WU-233-01-0A

Aloysius F. Hepp, David G. Hehemann, Stan A. Duraj, Eric B. Clark, William E. Eckles, and Phillip E. Fanwick

7. PERFORMING ORGANIZATION NAME(S) AND ADDRESS(ES)

8. PERFORMING ORGANIZATION REPORT NUMBER

National Aeronautics and Space Administration

Lewis Research Center

E-8718

Cleveland, Ohio 44135-3191

10. SPONSORINGMONITORING AGENCY REPORT NUMBER

9. SPONSORING/MONITORING AGENCY NAME(S) AND ADDRESS(ES)

National Aeronautics and Space Administration

Washington, D.C. 20546-0001

NASA TM-106558

11. SUPPLEMENTARY NOTES

Prepared for the Fall Meeting sponsored by the Materials Research Society, Boston, Massachusetts, November 29- December 3, 1993. Aloysius F. Hepp and Eric B. Clark, NASA Lewis Research Center; David G. Hehemann, School of Technology, Kent State University, Kent, Ohio 44242, and Senior Research Fellow-NASA Resident Research Associate at the Lewis Research Center (work funded by NASA Cooperative Agreement NCC3-318); Stan A. Duraj and William E. Eckles, Department of Chemistry, Cleveland State University, Cleveland, Ohio 44115 (work funded by NASA Cooperative Agreement NCC3-162); and Phillip E. Fanwick, Department of Chemistry, Purdue University, West Lafayette, Indiana 47907 (work funded by NASA Cooperative Agreement NCC3-246). Responsible person, Aloysius F. Hepp, organization code 5410, (216) 433-3835.

\begin{tabular}{|l|l}
\hline 12a. DISTRIBUTION/AVAILABILITY STATEMENT & 12b. DISTRIBUTION CODE
\end{tabular}

Unclassified - Unlimited

Subject Category 23

13. ABSTRACT (Maximum 200 words)

Neutral metal dithiocarbamate complexes $\left(\mathrm{M}\left(\mathrm{NR}_{2} \mathrm{CS}_{2}\right)_{\mathrm{x}}\right)$ are well-known precursors to metal sulfides, a class of materials with numerous technological applications. We are involved in a research effort to prepare new precursors to metal sulfides using simple, reproducible synthetic procedures. We describe the results of our synthetic and characterization studies for $\mathrm{M}=\mathrm{Fe}, \mathrm{Co}, \mathrm{Ni}, \mathrm{Cu}$, and In. For example, treatment of metallic indium with tetramethylthiuramdisulfide (tmtd) in 4-methylpyridine (4-Mepy) at $25^{\circ} \mathrm{C}$ produces a new homoleptic indium (III) dithiocarbamate, $\operatorname{In}\left(\mathrm{N}\left(\mathrm{CH}_{3}\right)_{2} \mathrm{CS}_{2}\right)_{3}(\mathrm{I})$, in yields of over $60 \%$. The indium (III) dithiocarbamate was characterized by X-ray crystallography; (I) exists in the solid state as discrete distorted-octahedral molecules. Compound (I) crystallizes in the P1bar (No. 2) space group with lattice parameters: $a=9.282(1) \AA, b=10.081(1) \AA, c=12.502 \AA, \alpha=73.91(1)^{\circ}, \beta=70.21(1)^{\circ}, \gamma=85.84(1)^{\circ}$, and $Z=2$. $\mathrm{X}$-ray diffraction and mass spectral data were used to characterize the products of the analogous reactions with $\mathrm{Fe}, \mathrm{Co}$, $\mathrm{Ni}$, and $\mathrm{Cu}$. We discuss both use of dithiocarbamates as precursors and our approach to their preparation.

14. SUBJECT TERMS

Dithiocarbamate; Structure; Synthesis; Metal powder

15. NUMBER OF PAGES 8

16. PRICE CODE

$\mathrm{A} 02$

17. SECURITY CLASSIFICATION OF REPORT

Unclassified
18. SECURITY CLASSIFICATION OF THIS PAGE Unclassified
19. SECURITY CLASSIFICATION OF ABSTRACT Unclassified 